\title{
CURRENT PANORAMA OF ANTERIOR CRUCIATE LIGAMENT RECONSTRUCTION SURGERY IN BRAZIL
}

\author{
PANORAMA ATUAL DA RECONSTRUÇÃO DO LIGAMENTO \\ CRUZADO ANTERIOR NO BRASIL
}

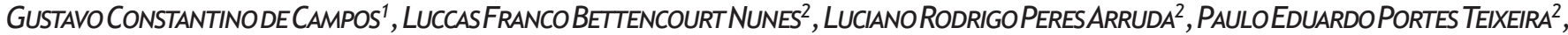

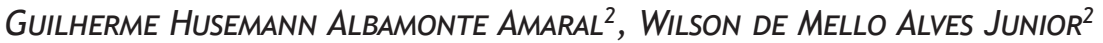

1. Orthopedics and Traumatology Department, Universidade Estadual de Campinas (UNICAMP), Campinas, SP, Brazil.

2. Instituto Wilson Mello, São Paulo, SP, Brazil.

\begin{abstract}
Objective: This study aims to establish the current panorama of the anterior cruciate ligament reconstruction surgery in Brazil. Methods: A survey that consisted of a 24 -item questionnaire including surgeon's demographics, preferred technique, graft selection, graft positioning, use of braces, drains, antibiotic prophylaxis and most common complications was conducted at the last three editions of a national knee surgery event. Results: Six hundred eight questionnaires were analyzed. Brazilian knee surgeons are mostly male, with mean age of 42 years (26-68) and are affiliated to at least one orthopedic society. Thirty-six percent (36\%) perform more than 50 reconstructions per year. The preferred graft is the hamstring tendons graft (64\%). The frequency of use of anatomical technique increased approximately from 55\% from 2011 to 2013, to 85.5\% in 2015 ( $p<0.001$ ). From 2011 to 2015, there was a progressive reduction from $56.8 \%$ to $18.1 \%$ in the frequency of use of transtibial femoral tunnel drilling $(p<0.001)$. Conclusion: Our findings show that Brazilian knee surgeons' preferences are evolving according to the current world practice. Level of Evidence V, Economic and Decision analysis study.
\end{abstract}

Keywords: Anterior Cruciate Ligament. Knee. Surgery. Reconstruction. Survey.

\section{RESUMO}

Objetivo: O presente estudo tem como objetivo estabelecer o panorama atual da cirurgia de reconstrução do ligamento cruzado anterior no Brasil. Métodos: Nas últimas três edições de um evento nacional de cirurgia do joelho, realizou-se uma pesquisa que consistiu em um questionário de 24 itens incluindo dados demográficos do cirurgião, técnica preferida, seleção do enxerto, posicionamento do enxerto, uso de órteses, drenos, profilaxia antibiótica e complicações mais comuns. Resultados: Seiscentos e oito questionários foram analisados. O cirurgião brasileiro de joelho é majoritariamente do sexo masculino, tem idade média de 42 anos (26-68) e é afiliado a pelo menos uma sociedade ortopédica. Trinta e seis por cento (36\%) realizam mais de 50 reconstruções por ano. O enxerto preferido é o enxerto de tendões isquiotibiais (64\%). A frequência de uso da técnica anatômica aumentou de 55\% nos anos de 2011 e 2013 para 85,5\% em 2015 ( $p<0,001)$. Após 2011, também foi observada redução progressiva de 56,8\% para 18,1\% até 2015 na frequência de uso da técnica de perfuração do túnel femoral transtibial $(p<0,001)$. Conclusão: Nossos achados mostram que os cirurgiões brasileiros de joelho estão evoluindo de acordo com a prática mundial atual. Nível de evidência V, Análise econômica e de decisão.

Descritores: Ligamento cruzado anterior. Joelho. Cirurgia. Reconstrução. Inquéritos e Questionários.

Citation: Campos GC, Nunes LFB, Arruda LRP, Teixeira PEP, Amaral GHA, Alves Jr WM. Current panorama of the anterior cruciate ligament reconstruction surgery in Brazil. Acta Ortop Bras. [online]. 2019;27(3):146-51. Available from URL: http://www.scielo.br/aob.

\section{INTRODUCTION}

Rupture of the anterior cruciate ligament $(\mathrm{ACL})$ of the knee is an extremely common sports injury, with an estimated number of 300,000 new cases every year in the United States alone. ${ }^{1,2}$ Surgical procedure for ligament reconstruction is one of the most performed orthopedic surgeries ${ }^{3}$ and is currently the standard of care, specially for active individuals who aim to return to high-level sports activity. ${ }^{2}$
Since its first description, ACL reconstruction surgery has evolved considerably, specially in the last three decades. First proposals of ACL repair by suture appeared at the beginning of the 20th century. ${ }^{4}$ The 1960's and 70's witnessed the extra-articular procedures, such as the Lemaire ${ }^{5}$ or Andrews ${ }^{6}$ procedures, with poor long term results. The attention, therefore, turned to ACL reconstruction, and the patellar tendon would soon become the gold standard graft.

All authors declare no potential conflict of interest related to this article.

This study was conducted at Núcleo de Estudos do Instituto Wilson Mello, at the address Rua José Rocha Bonfim, 214, Ed. Chicago, 10. andar, Condomínio Praça Capital, Jardim Santa Genebra, CEP 13080-650, Campinas, SP, Brazil

Correspondence: Rua José Rocha Bonfim, 214, Ed. Chicago, Condomínio Praça Capital Bairro Jardim Santa Genebra, Campinas, SP, Brazil. gustavoccampos@hc.unicamp.br 
The advent of arthroscopy revolutionized knee surgery, but also brought a new concept of isometric graft positioning, with transtibial femoral tunnel drilling. ${ }^{7}$ The arthroscopic isometric reconstruction became very popular in the last two decades of the 20th century, but often led to non-anatomic placement of femoral tunnels. ${ }^{8}$ The 21 th century began with the introduction of the anatomical anterior cruciate reconstruction concept by Freddy Fu and coworkers. ${ }^{9}$ Since then, the pursuit of the ideal graft positioning has led to the so-called "anatomic" single-bundle reconstruction techniques, which can be accomplished by either by an anteromedial approach ${ }^{10}$ as well as an outside-in femoral drilling. ${ }^{11}$

Today, there is still no consensus about the best $\mathrm{ACL}$ reconstruction technique. We present the current panorama of the anterior cruciate ligament reconstruction surgery in Brazil. We were also able to analyze the recent evolution of Brazil's knee surgeons preferences, since the present study includes data from the last 6 years.

\section{MATERIALS AND METHODS}

A survey was conducted at the last three editions of a national biannual knee surgery event that has the participation of most of the knee surgeons from all around the country. Local ethics committee waived the use of a consent term since there were no patients involved. Therefore, there was no consent form.

The survey was exactly the same in all three occasions and consisted of a 24-item questionnaire that was offered to all participants. (Appendix 1) It comprised questions about surgeon's demographics (gender, age, region of origin, year of graduation, titles and number of ACL surgeries per year), preferred technique, graft selection, graft positioning, femoral drilling technique, use of braces, drains, antibiotic prophylaxis and most common complications. The tunnel positioning was further analyzed by the use of figures. (Appendix 1) The questionnaires were filled independently by each surgeon, without any interference. No information was given and it should contain only the personal experience of each surgeon. The results were organized in an Excel (Microsoft Inc., California, USA) table. Data was presented in absolute frequency (n) and relative frequency (\%). To analyze the frequencies and the association of categoric data it was used the Chi-square test or the Fisher's exact test when appropriate. Statistical analysis was conducted using the software PASW statistic 18.0 (SPSS Inc., Chicago, USA). Significance level (alpha) of $5 \%(p<0,05)$ was adopted.

\section{RESULTS}

A total of 805 questionnaires were distributed in the three events, of which 608 were completed and returned (75\% response). Surgeon's demographics are shown in Table 1. The vast majority of Brazilian knee surgeons that attended to the events were male $(98,8 \%)$, with a mean age of 42 years old (26-68) and has specialist title and is affiliated to at least one orthopaedic society. Regarding the number of ACL procedures per year, $36 \%$ perform more than 50 reconstructions per year, $15 \%$ between 41 and 50 and $15 \%$ between 31 and 40 reconstructions. Of all surgeons, $97 \%$ perform arthroscopic surgery. The preferred graft is the hamstring tendons graft $(64,4 \%)$. The patellar tendon is preferred by $10,4 \%$, and $25,2 \%$ of the surgeons reported to use either hamstring or patellar tendon graft. The preferred femoral fixation device is interference screw followed by suspensory devices. Most of the surgeons use only interference screw for tibial fixation $(79,3 \%)$. (Table 2) Forty six percent of the surgeons use antibiotic prophylaxis within the first 24 hours of the procedure, $26 \%$ only at anesthesia, 4,3\% report antibiotic use within 48 hours, 19,8\% use for more than 48 hours and 3,5 don't use antibiotic prophylaxis. The use of surgical drain fell from 40\% to 25\% from 2011 to 2015 . $(p<0.05$, Figure $1 E)$
Table 1. Demographics.

\begin{tabular}{|c|c|c|}
\hline Characteristics & $\begin{array}{c}\text { Values/ } \\
\text { Occurrence }\end{array}$ & a $P$-Value \\
\hline Age [mean (range)] (anos) & $42(26-68)$ & -.---.-- \\
\hline \multicolumn{3}{|l|}{ Gender [n (\%)] } \\
\hline Men & $601(98.8 \%)$ & \multirow{2}{*}{$<0.001$} \\
\hline Women & $7(1.2 \%)$ & \\
\hline \multicolumn{3}{|c|}{ Member of at least 1 medical society [n (\%)] } \\
\hline Yes & $581(95.6 \%)$ & \multirow{2}{*}{$<0.001$} \\
\hline No & $27(4.4 \%)$ & \\
\hline \multicolumn{3}{|c|}{ Number of ACL reconstructions per year [n (\%)] } \\
\hline 01 to 10 & $52(8.6 \%)$ & \multirow{6}{*}{$<0.001$} \\
\hline 11 to 20 & $84(13.8 \%)$ & \\
\hline 21 to 30 & $80(13.2 \%)$ & \\
\hline 31 to 40 & $68(11.2 \%)$ & \\
\hline 41 to 50 & $100(16.4 \%)$ & \\
\hline$>50$ & $224(36.8 \%)$ & \\
\hline
\end{tabular}

${ }^{a} \mathrm{p}$-values for Chi-square tests. ACL: anterior cruciate ligament

Table 2 - Description of surgical preferences.

\begin{tabular}{|c|c|c|}
\hline Characteristics & Values/Ocurrence & a $P$-Value \\
\hline \multicolumn{3}{|l|}{ Surgical technique of preference [n (\%)] } \\
\hline Arthroscopic & $590(97.0 \%)$ & \multirow{2}{*}{$<0.001$} \\
\hline Open & $18(3.0 \%)$ & \\
\hline \multicolumn{3}{|l|}{ Graft preference [n (\%)] } \\
\hline Hamstring tendons & $391(64.4 \%)$ & \multirow{3}{*}{$<0.001$} \\
\hline Patellar tendon & $63(10.4 \%)$ & \\
\hline Either hamstring tendons or patellar tendon & $153(25.2 \%)$ & \\
\hline \multicolumn{3}{|l|}{ Femoral fixation device of preference [n (\%)] } \\
\hline Endobutton & $139(22.9 \%)$ & \\
\hline Ezloc & $4(0.7 \%)$ & \\
\hline $\begin{array}{l}\text { Interference screw } \\
\end{array}$ & $244(40.1 \%)$ & \\
\hline Interference screw and/or Endobutton & $23(3.8 \%)$ & \\
\hline Interference screw and or press-fit & $2(0.3 \%)$ & \\
\hline Transverse screw & $147(24.2 \%)$ & \\
\hline Transverse screw and or Endobutton & $21(3.5 \%)$ & \\
\hline $\begin{array}{c}\text { Transverse and/or Interference } \\
\text { screw and/or Endobutton }\end{array}$ & $2(0.3 \%)$ & \\
\hline Transverse and/or Interference screw & $17(2.8 \%)$ & \\
\hline Thight rope & $1(0.2 \%)$ & \\
\hline Transverse screw & $5(0.8 \%)$ & \\
\hline Other & $2(0.3 \%)$ & \\
\hline \multicolumn{3}{|l|}{ Tibial Fixation [n (\%)] } \\
\hline Agraaf & $2(0.3 \%)$ & \\
\hline Interference screw & $482(79.3 \%)$ & \\
\hline Interference screw and origin & $2(0.3 \%)$ & \\
\hline Interference screw and/or Agraaf & $64(10.5 \%)$ & \\
\hline Interference screw and/or AO cancellous screw & $36(5.9 \%)$ & \\
\hline Interference screw and/or Washerlock & $11(1.8 \%)$ & \\
\hline $\mathrm{AO}$ cancellous screw & $3(0.5 \%)$ & \\
\hline AO cancellous screw and/or Washerlock & $4(0.7 \%)$ & \\
\hline Thight rope & $1(0.2 \%)$ & \\
\hline Other & $2(0.3 \%)$ & \\
\hline \multicolumn{3}{|l|}{ Use of surgical drain [n (\%)] } \\
\hline Yes & $237(39.1 \%)$ & \multirow{2}{*}{$<0.001$} \\
\hline No & $369(60.9 \%)$ & \\
\hline \multicolumn{3}{|l|}{ Use of Brace [n (\%)] } \\
\hline Yes & $74(12.2 \%)$ & \multirow{2}{*}{$<0.001$} \\
\hline No & $532(87.8 \%)$ & \\
\hline \multicolumn{3}{|l|}{ Use of Antibiotics } \\
\hline No & $21(3.5 \%)$ & \multirow{5}{*}{$<0.001$} \\
\hline Yes at anesthetic induction & $159(26.2 \%)$ & \\
\hline Yes for $24 \mathrm{~h}$ & $280(46.2 \%)$ & \\
\hline Yes for $48 \mathrm{~h}$ & $26(4.3 \%)$ & \\
\hline Yes for more than $48 \mathrm{~h}$ & $120(19.8 \%)$ & \\
\hline
\end{tabular}

${ }^{a} \mathrm{p}$-values for Chi-square tests. 
In 2011, 2013 and 2015 there were a higher frequency of hamstring graft use compared to patellar tendon graft or use of either graft $(p<0,05)$, without a change over the years. (Figure 1D) The frequency of use of anatomical technique increased approximately $55 \%$ in the years 2011 and 2013, to 85.5\% in 2015. ( $P<0.001$, Figure 2) After 2011 it was also observed progressive reduction from $56.8 \%$ to $18.1 \%$ by 2015 in the frequency of use of transtibial femoral tunnel drilling technique. ( $P<0.001$, Figure $1 \mathrm{~B})$

No differences were observed between the frequency of use of open or arthroscopic technique, use of double-bundle technique, brace, and graft choice between 2011, 2013 and 2015. ( $P>0.05$, Figure 1A, Figure 1C, Figure 1D, Figure 1F)

The preferred incision for harvesting hamstring tendons was the vertical longitudinal incision, followed by oblique and transverse incision. (Figure 3)

Association between $A C L$ reconstruction frequency and other procedures with surgeon's age.

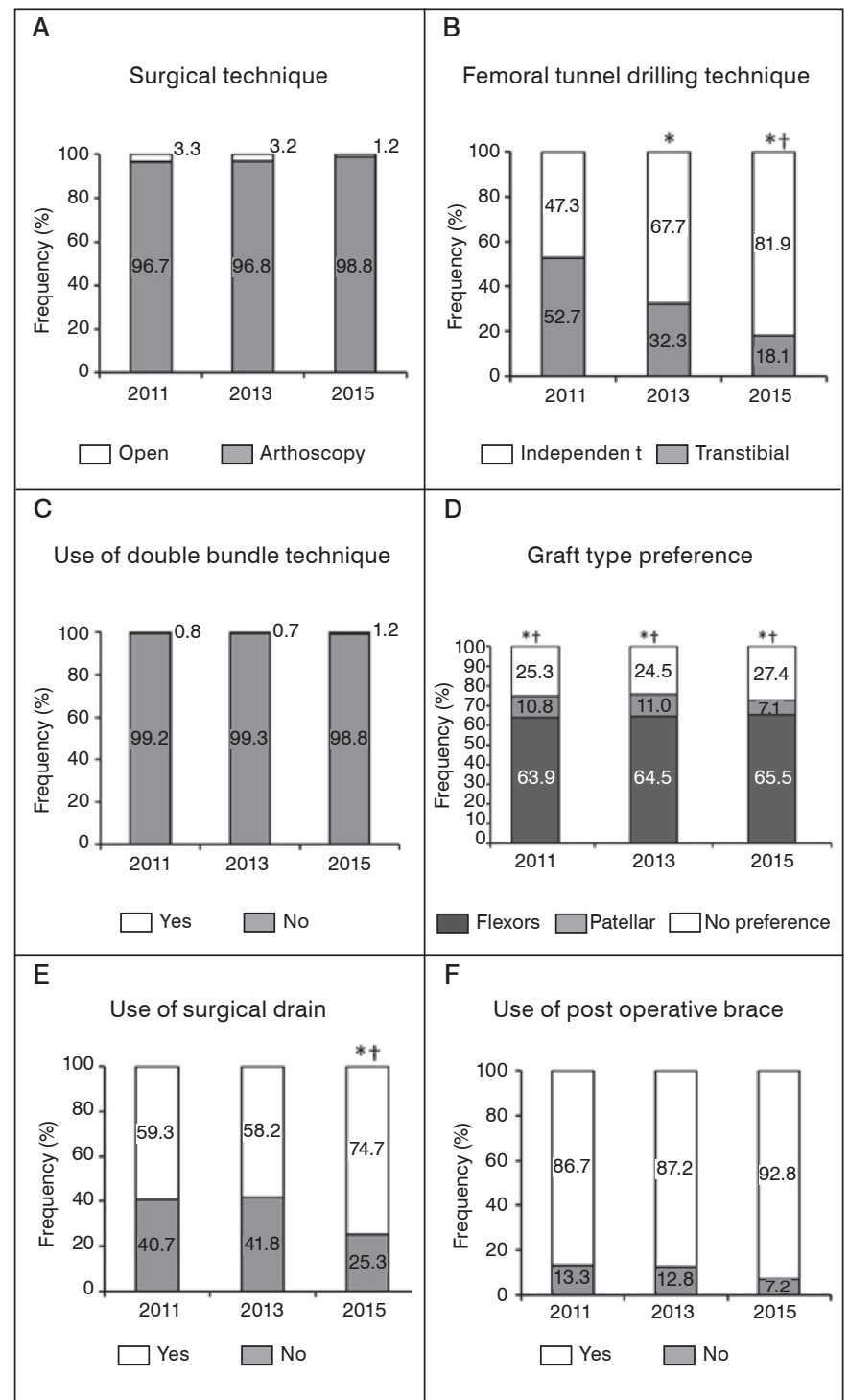

${ }^{*} p<0.05$ compared to 2011. $\dagger p<0.05$ compared to 2013 . D: Comparison of frequency of utilization of graft types between 2011,2013 and 2015 . ${ }^{*} p<0.05$ for comparison between flexor graft against patellar and no preference. $\mathrm{tp}<0.05$ for comparison between patellar frequency against flexor and no preference

Figure 1. Comparison of frequency of utilization of medical procedures between 2011, 2013 and 2015.

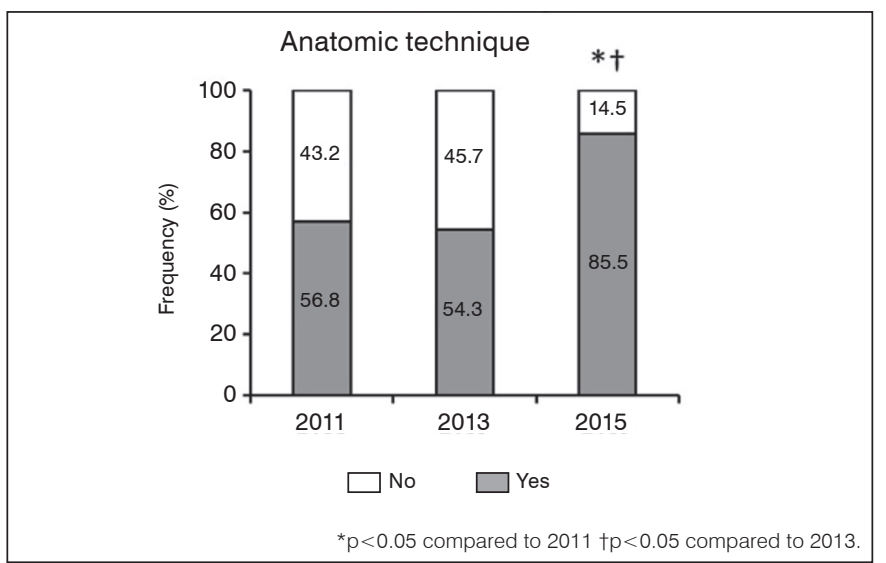

Figure 2. Frequency of utilization of the anatomic technique in 2011 , 2013 and 2015

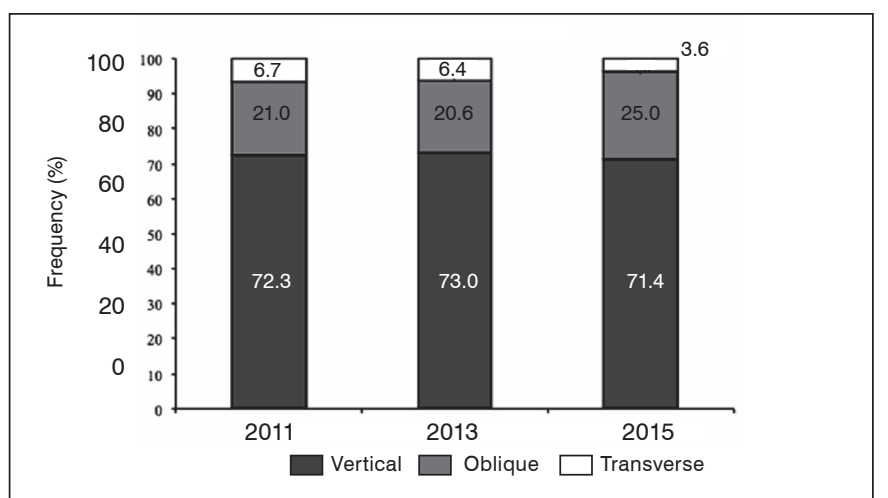

Figure 3. Type of hamstrings harvest incision.

A significant association between $A C L$ reconstruction frequency per year and surgeon's age $(P<0.001)$ was identified. (Table 3$)$ Professionals aged 35 to 60 had the highest number of ACL reconstructions/year, followed by professionals under the age of 35 years and above 60 years. Additionally, a significant correlation between the use of antibiotics ( $P=0.002$ ) was observed. (Table 3 ) The most common antibiotic prophylaxis regimen adopted was within 24 hours from anesthesia, followed by the use above 48h, between 24 and $48 \mathrm{~h}$ and no antibiotic use. There was no significant association between the frequency of $A C L$ reconstruction/year and the femoral tunnel drilling technique used $(P=0.381)$. (Table 3 ) Association Between the Report of using Anatomic Technique and Procedure Actually Used.

We compared the report of the use of anatomic technique and the tunnel positioning demonstrated in the questionnaires' figures. Only $84.5 \%$ of the professionals who reported use of anatomical technique demonstrated proper tunnel positioning technique. It was observed that $98.6 \%$ and $85 \%$ of all professionals demonstrated proper positioning of the tibial tunnel and femoral tunnel, respectively ( $P<0.001)$. In addition, $24 \%$ of the surgeon's that are using the transtibial technique claim that they are using anatomic reconstruction technique, and $27.8 \%$ of them believe that they are achieving the anatomic femoral positioning. (Table 4)

\section{Complications After ACL Reconstruction.}

The most common reported complications after ACL reconstruction using the transtibial and anatomical techniques were anterior pain (34.8\% and $32.4 \%$, respectively), persistent muscle atrophy $(28.8 \%$ and $40.5 \%$, respectively) and difficulty in achieving full flexion 
Table 3. Multiple association.

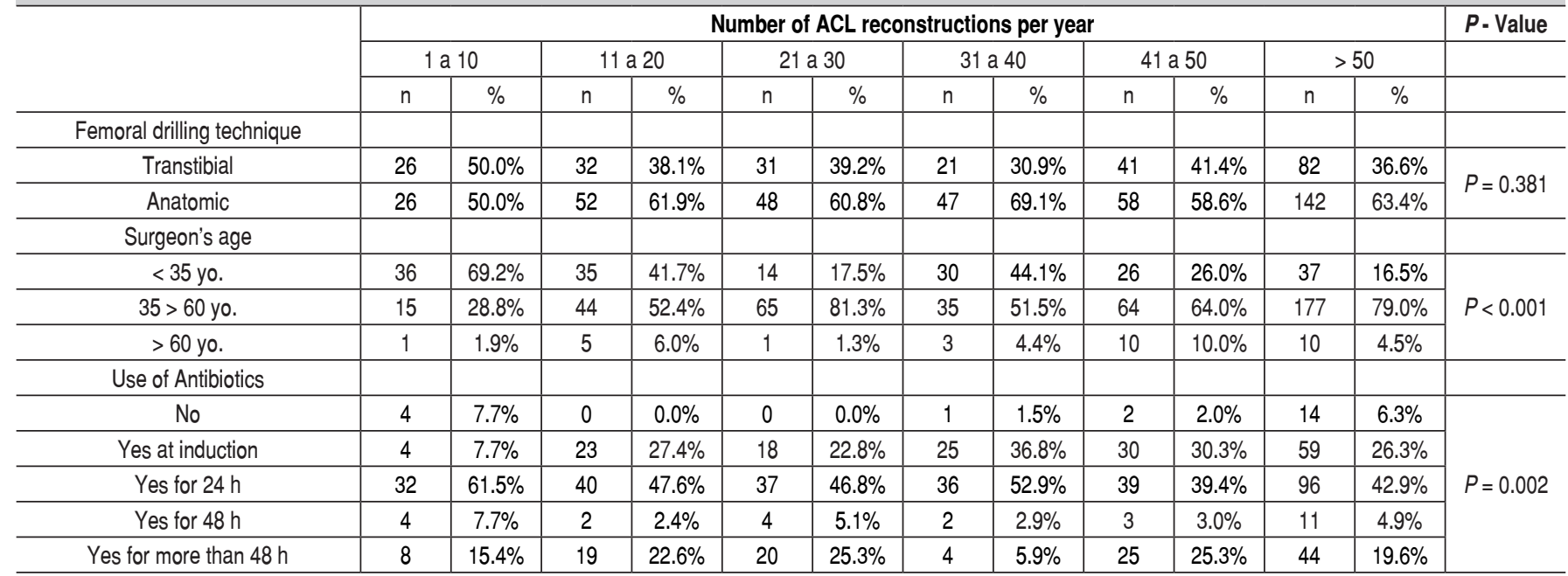

Table 4. Association between the report and actual use of anatomic technique.

\begin{tabular}{|c|c|c|c|c|c|}
\hline & \multicolumn{4}{|c|}{ "I use anatomic technique" } & \multirow{3}{*}{$P$-Value } \\
\hline & \multicolumn{2}{|c|}{ Yes } & \multicolumn{2}{|c|}{ No } & \\
\hline & $\mathbf{n}$ & $\%$ & $\mathbf{n}$ & $\%$ & \\
\hline \multicolumn{6}{|l|}{ Tibial tunnel positioning } \\
\hline 1 or 2 (anatomic position) & 356 & $98.6 \%$ & 168 & $68.6 \%$ & \multirow{2}{*}{$P<0.001$} \\
\hline 3 (non-anatomic position) & 5 & $1.4 \%$ & 77 & $31.4 \%$ & \\
\hline \multicolumn{6}{|l|}{ Femoral tunnel positioning } \\
\hline 2 ou 3(anatomic position) & 307 & $85.0 \%$ & 102 & $41.6 \%$ & \multirow[b]{2}{*}{$P<0.001$} \\
\hline $\begin{array}{c}1,4 \text { ou } 5 \text { (non- } \\
\text { anatomic position) }\end{array}$ & 54 & $15.0 \%$ & 143 & $58.4 \%$ & \\
\hline \multicolumn{6}{|l|}{ Femoral drilling technique } \\
\hline Transtibial & 56 & $15.5 \%$ & 177 & $72.2 \%$ & \multirow{2}{*}{$P<0.001$} \\
\hline Anatomic & 305 & $84.5 \%$ & 68 & $27.8 \%$ & \\
\hline
\end{tabular}

(11.6\% and $4.0 \%$ respectively) followed by difficulty in full extension, extension gain, flexion gain, hemarthrosis, stiffness and persistent instability, which alone did not exceed $10 \%$ of cases. (Table 5) Additionally, a single case (0.3\%) of thromboembolism was reported after ACL reconstruction of anatomical access. Only 7.3\% and $5.1 \%$ of professionals using the transtibial and anatomical aproach, respectively, reported having not observed any complications after $\mathrm{ACL}$ reconstruction. (Table 5)

\section{DISCUSSION}

The present study defined the current panorama of the anterior cruciate ligament reconstruction surgery in Brazil. To the best of our knowledge, this is the first study that analyzed the evolution of the Brazilian knee surgeon's preferences.

Our results shows that most of Brazilian knee surgeons are performing an adequate number of ACL procedures each year, in accordance to the opinion that a surgeon should perform at least 30 procedures per year to be considered a "high volume" surgeon and ensure lesser complication incidence and better cost-effectiveness. ${ }^{12,13}$ A recent similar study from Croatia found that almost $75 \%$ of respondents performed four or less ACL reconstructions per month, meaning less than fifty ACL reconstructions per year. ${ }^{14}$ The preferred choice of graft (hamstring tendons) is in accordance to the graft's choice observed around the world. ${ }^{15}$ The semi-tendinosus tendon with or without the gracilis tendon, started to gain popularity in the 80's and has become the more commonly used graft for years now. Nevertheless, patellar tendon graft is still considered
Table 5. Complications.

\begin{tabular}{c|c|c|c|c}
\hline \multirow{2}{*}{ Complications } & \multicolumn{4}{|c}{ Femoral Drilling Technique } \\
\cline { 2 - 5 } & \multicolumn{2}{|c|}{ Transtibial } & \multicolumn{2}{c}{ Anatomic } \\
\cline { 2 - 5 } & $\mathbf{n}$ & $\%$ & $\mathbf{n}$ & $\%$ \\
\hline Persistent muscle atrophy & 67 & $28.8 \%$ & 151 & $40.5 \%$ \\
\hline Difficulty to achieve total extension & 24 & $10.3 \%$ & 28 & $7.5 \%$ \\
\hline Difficulty to achieve total flexion & 27 & $11.6 \%$ & 15 & $4.0 \%$ \\
\hline Anterior pain & 81 & $34.8 \%$ & 121 & $32.4 \%$ \\
\hline Hemarthrosis & 0 & $0.0 \%$ & 8 & $2.1 \%$ \\
\hline Persistent instability & 10 & $4.3 \%$ & 10 & $2.7 \%$ \\
\hline Stiffness & 2 & $0.9 \%$ & 4 & $1.1 \%$ \\
\hline Thromboembolism & 0 & $0.0 \%$ & 1 & $0.3 \%$ \\
\hline None & 17 & $7.3 \%$ & 19 & $5.1 \%$ \\
\hline
\end{tabular}

the gold standard by several surgeons. ${ }^{16}$ Although the double bundle technique can't be considered a new approach to the ACL reconstruction, it's use among Brazilian surgeons was reflected to be predominantly nonexistent for all the time points. We believe that aspects such as technique learning curve and costs are the main reason why we see this scenario in Brazil. This finding was somewhat expected as the popularity of the double bundle technique has never been large among Brazilian surgeons.

The most important finding of the present study is the trend to the gradual abandonment of the isometric positioning technique that use transtibial approach for femoral drilling. We observed a progressive reduction in the frequency of use of transtibial femoral tunnel drilling technique and a higher frequency of the single-bundle anatomic technique with independent drilling, either through the anteromedial portal or outside-in technique, which also is in accordance to the world trend. Despite the fact that the discussion is far from over, there is a crescent number of studies showing that anatomic reconstruction could restore ACL function more closely to the native ligament, with better biomechanical and clinical results, specially regarding knee rotation. ${ }^{7}$ Another interesting finding was the misconception of the so-called "anatomic technique". Only $84.5 \%$ of the professionals who reported use of anatomical technique demonstrated proper tunnel positioning technique using the questionnaire's figures. Moreover, $24 \%$ of the surgeons reporting the use of transtibial femoral drilling technique also reported to be using anatomic reconstruction technique. It is known that transtibial femoral tunnel drilling results in non-anatomic placement of the femoral tunnels. ${ }^{8,17}$ Literature also shows a confusion 
regarding the proper report of the chosen ACL reconstruction technique among articles. Van Eck et al., examined 74 studies that claimed to use "anatomic technique" for ACL reconstruction and found a gross under-reporting of specific operative technique data. ${ }^{18}$

When harvesting the hamstrings tendons we found a preference for longitudinal incision. It is known that iatrogenic injury to the infrapatellar branch of the saphenous nerve is a common complication during $\mathrm{ACL}$ reconstruction with hamstrings tendon. ${ }^{19} \mathrm{~A}$ recent systematic revision concluded that the available studies suggest less neurological damage if an oblique incision is used. ${ }^{20}$ Our finding on the use of post-operative brace after ACL reconstruction suggest a low indication of brace which have diminished over time and had never been greater than $14 \%$ of all the respondents of our survey. Our results may be justified by evidence ${ }^{21}$ that suggest that the use of post-operative brace have poor effect on pain control during the post-operative phase. However, different surgeons indicate the use of brace for different reasons such as protection and range of motion control. Perhaps a more interesting question would be to those who indicate bracing, what are the main reasons for prescribing this intervention.
Our study has some limitations. First of all, it is based on a survey. The answers may not reflect the real practice of each surgeon. Secondly, we did not investigates results, rehabilitation protocols, return to sports criteria or some other information that could be interesting. Thirdly, the vast majority of responders were male, which do not reflect totally the gender distribution of knee surgeons through our country. Still, it is in fact a predominantly male speciality in Brazil. However, our strength rely on the high number of responders and specially on the fact that data from 3 different events were analyzed, which made possible to observe shifts in preference trends through the past 6 years.

\section{CONCLUSION}

The current panorama of the anterior cruciate ligament surgery in Brazil shows that Brazilian knee surgeons preferences are in accordance to the current world practice, with recent substitution of isometric graft positioning through transtibial femoral tunnel drilling technique for anatomic positioning through independent femoral tunnel drilling technique.

AUTHORS' CONTRIBUTIONS: Each author has significantly contributed to this article. GCC (ORCID: 0000-0001-7811-7354): writing, statistical analysis and intellectual concept of the manuscript and development of the research project. LFBN (orcid 0000-0003-1588-3494): data collection and writing. LRPA (orcid 0000-0003-4729-4539): data collection and analysis. PEPT (orcid 0000-0003-3246-5059): revision and intellectual concept. GHAA (orcid 0000-0001-69622519): data analysis, writing and revision. WMAJ (orcid 0000-0003-0736-191X): critical analysis of intellectual concept and final approval of the manuscript version to be published. *ORCID (Open Researcher and Contributor ID).

\section{REFERENCES}

1. Salmon L, Russell V, Musgrove T, Pinczewski L, Refshauge K. Incidence and risk factors for graft rupture and contralateral rupture after anterior cruciate ligament reconstruction. Arthroscopy. 2005;21(8):948-57.

2. Hewett TE, Di Stasi SL, Myer GD. Current concepts for injury prevention in athletes after anterior cruciate ligament reconstruction. Am J Sports Med. 2013;41(1):216-24

3. Crawford SN, Waterman BR, Lubowitz JH. Long-term failure of anterior cruciate ligament reconstruction. Arthroscopy. 2013;29(9):1566-71.

4. Schindler OS. Surgery for anterior cruciate ligament deficiency: a historical perspective. Knee Surg Sports Traumatol Arthrosc. 2012;20(1):5-47.

5. Chambat P, Guier C, Sonnery-Cottet B, Fayard JM, Thaunat M. The evolution of ACL reconstruction over the last fifty years. Int Orthop. 2013;37(2):181-6.

6. Andrews JR, Sanders R. A "mini-reconstruction" technique in treating anterolateral rotatory instability (ALRI). Clin Orthop Relat Res. 1983;(172):93-6.

7. Rayan F, Nanjayan SK, Quah C, Ramoutar D, Konan S, Haddad FS. Review of evolution of tunnel position in anterior cruciate ligament reconstruction. World J Orthop. 2015;6(2):252-62.

8. Strauss EJ, Barker JU, McGill K, Cole BJ, Bach BR Jr, Verma NN. Can anatomic femoral tunnel placement be achieved using a transtibial technique for hamstring anterior cruciate ligament reconstruction? Am J Sports Med. 2011;39(6):1263-9.

9. Ferretti M, Ekdahl M, Shen W, Fu FH. Osseous landmarks of the femoral attachment of the anterior cruciate ligament: an anatomic study. Arthroscopy. 2007;23(11): 1218-25

10. Chalmers PN, Mall NA, Cole BJ, Verma NN, Bush-Joseph CA, Bach BR Jr. Anteromedial versus transtibial tunnel drilling in anterior cruciate ligament reconstructions: a systematic review. Arthroscopy. 2013;29(7):1235-42.

11. Arnold MP, Duthon V, Neyret P, Hirschmann MT. Double incision iso-anatomical ACL reconstruction: the freedom to place the femoral tunnel within the anatomical attachment site without exception. Int Orthop. 2013;37(2):247-51.

12. Paxton EW, Namba RS, Maletis GB, Khatod M, Yue EJ, Davies M, et al. A prospective study of 80,000 total joint and 5000 anterior cruciate ligament reconstruction procedures in a community-based registry in the United States.
J Bone Joint Surg Am. 2010;92 Suppl 2:117-32

13. Katz JN, Barrett J, Mahomed NN, Baron JA, Wright RJ, Losina E. Association between hospital and surgeon procedure volume and the outcomes of total knee replacement. J Bone Joint Surg Am. 2004;86-A(9):1909-16.

14. Mahnik A, Mahnik S, Dimnjakovic D, Curic S, Smoljanovic T, Bojanic I. Current practice variations in the management of anterior cruciate ligament injuries in Croatia. World J Orthop. 2013;4(4):309-15.

15. Shaerf DA, Pastides PS, Sarraf KM, Willis-Owen CA. Anterior cruciate ligament reconstruction best practice: A review of graft choice. World J Orthop. 2014;5(1):23-9.

16. Shelbourne KD, Benner RW, Gray T. Return to Sports and Subsequent Injury Rates After Revision Anterior Cruciate Ligament Reconstruction With Patellar Tendon Autograft. Am J Sports Med. 2014;42(6):1395-400.

17. Robin BN, Jani SS, Marvil SC, Reid JB, Schillhammer CK, Lubowitz JH. Advantages and Disadvantages of Transtibial, Anteromedial Portal, and Outside-In Femoral Tunnel Drilling in Single-Bundle Anterior Cruciate Ligament Reconstruction: A Systematic Review. Arthroscopy. 2015;31(7):1412-7.

18. van Eck CF, Schreiber VM, Mejia HA, Samuelsson K, van Dijk CN, Karlsson J, et al."Anatomic" anterior cruciate ligament reconstruction: a systematic review of surgical techniques and reporting of surgical data. Arthroscopy. 2010;26(9 Suppl):S2-12.

19. Papastergiou SG, Voulgaropoulos H, Mikalef P, Ziogas E, Pappis G, Giannakopoulos I. Injuries to the infrapatellar branch(es) of the saphenous nerve in anterior cruciate ligament reconstruction with four-strand hamstring tendon autograft: vertical versus horizontal incision for harvest. Knee Surg Sports Traumatol Arthrosc. 2006;14(8):789-93.

20. Ruffilli A, De Fine M, Traina F, Pilla F, Fenga D, Faldini C. Saphenous nerve injury during hamstring tendons harvest: Does the incision matter? A systematic review. Knee Surg Sports Traumatol Arthrosc. 2017;25(10):3140-5.

21. Hiemstra LA, Heard SM, Sasyniuk TM, Buchko GL, Reed JG, Monteleone BJ. Knee immobilization for pain control after a hamstring tendon anterior cruciate ligament reconstruction: a randomized clinical trial. Am J Sports Med. 2009;37(1):56-64 


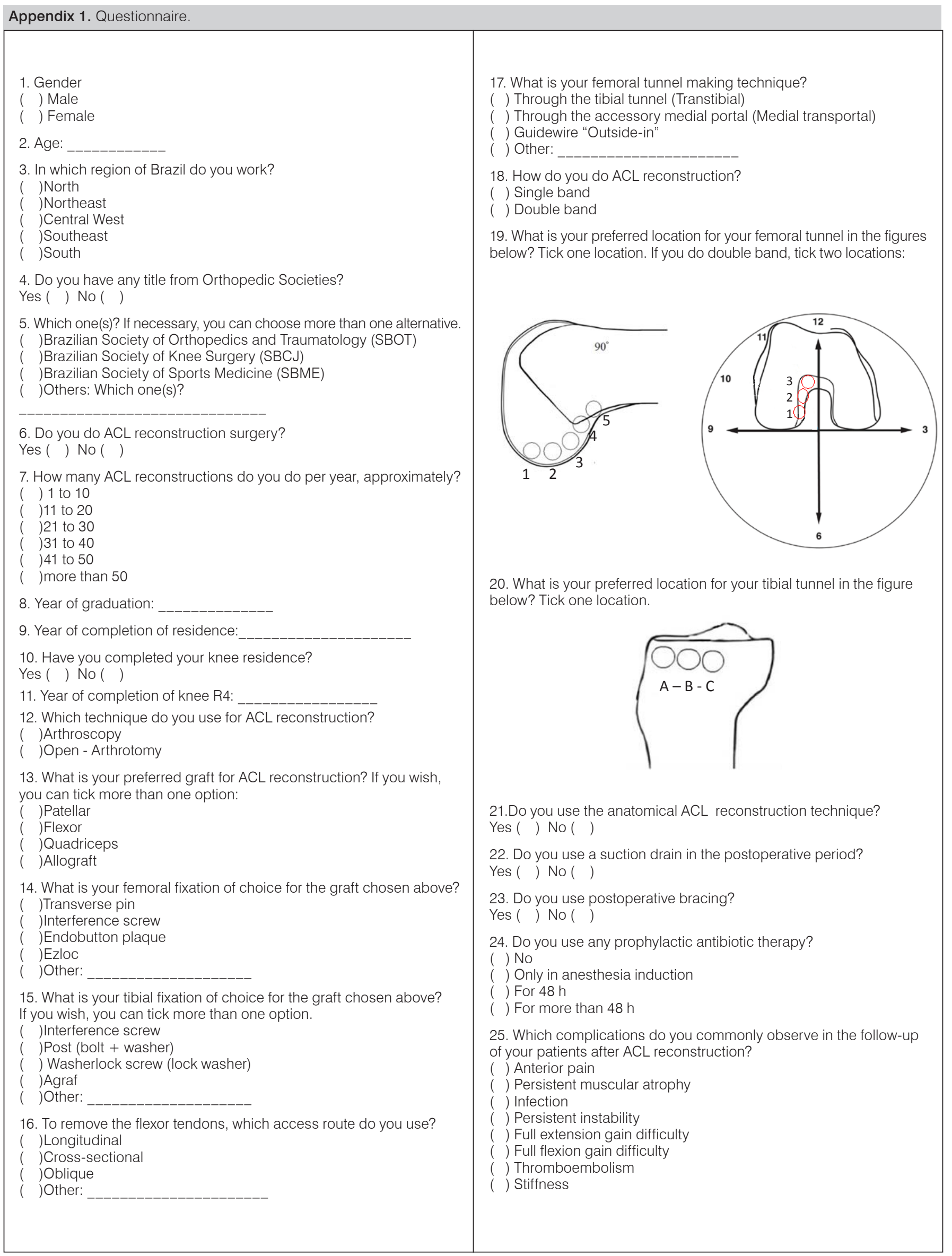

